DOI 10.17816/transsyst201843s1246-252

(C) P. Yan

Tongji University Maglev Transportation Engineer R\&D Center (Shanghai, China)

\title{
PROGRESS MADE AND PROSPECT OF CHINA'S MAGLEV TRANSPORTATION TECHNOLOGY STANDARDIZATION
}

Background: In order to standardize maglev transportation engineering and its operation, the research of maglev transportation technical standards becomes important. Based on the analysis of the growth of rail transit, the acceleration of maglev transportation engineering, the China's standardization regulation and the maglev transportation technology standardization practice,

Aim: This paper proposes the basic principles for establishing maglev transportation standard system and the framework of maglev transportation technical standard system, introducing China's maglev transportation technology standardization mechanism, its achievements, prospects and experiences.

Results: By the end of 2017, China had developed 12 maglev transportation technical industry and provincial standards.

Conclusion: There are 12 maglev transportation technical industry standards and social organization standards under development.

Keywords: Maglev, transportation, engineering, technology, standard, standardization, system framework.

\section{INTRODUCTION}

The development of urbanization in China and the increasing demand for public transportation facilities have promoted the development of rail transit in China and the application of technological research and engineering in China's maglev transportation system. The standardization of maglev transportation technology has received attention from standardization bodies at all levels and the related enterprises and institutions. It has achieved initial results. The application and the commercial operation of maglev transportation bring a more urgent demand for maglev transportation standards.

\section{URBANIZATION PROMOTES RAPID DEVELOPMENT OF RAIL TRANSPORTATION}

By the end of 2017, the permanent urban population in China had reached 813.47 million, and the urbanization rate of permanent residents had reached $58.52 \%$. In the past five years, the average annual increment of permanent urban 
population was 13 million [1]. To meet the public travel demand, the construction and operation of China's conventional railways, high-speed railways, and urban rail transit have been rapidly developed.

\subsection{Rapid development of rail transit construction and operation}

By the end of 2017, the mileage of China's railways has reached 127000 kilometers, including 25000 kilometers of high-speed railways [2]. The mileage of urban rail transit reached more than 5000 kilometers.

In 2017 , the number of passengers sent by railways reached 3.08 billion [3], an increase of $46 \%$ from 2.11 billion people in 2013, the passenger volume of urban rail transit reached 18.48 billion person-times [4], which was an increase of $69.2 \%$ from 10.92 billion person-times in 2013 .

\subsection{Maglev Transportation Technology Gets New Development Opportunities}

Maglev transportation brings advantages due to its technical characteristics and gets better development opportunities in the comprehensive system of rail transit in China.

The high-speed maglev transportation with a maximum speed of up to $500 \mathrm{~km} / \mathrm{h}$ and constant-current magnetic levitation has unique advantages. It can greatly increase passengers' long-distance travel efficiency in long-distance travel of over 1000 kilometers. Medium and Low speed maglev transit has low noise and strong climbing ability. The advantage of small turning radius has potential for development in urban public transportation and tourism and tourist routes.

Based on the technological advantages of maglev transportation technology, maglev transportation technology research has been highly valued in China, and the application of maglev transportation engineering has also entered the initial stage of development. By the end of 2017, the operating mileage of China's maglev transportation had reached 57.9 kilometers, including the 29.1 kilometers Shanghai high-speed maglev demonstration line, the 18.6 kilometers Changsha Maglev line, and the 10.2 kilometers Beijing S1 line.

\section{ESTABLISHING A FRAMEWORK FOR MAGLEV TRANSPORTATION TECHNICAL STANDARDS}

The engineering development of maglev transportation puts forward requirements for maglev transportation technical standards. The standardization 
of maglev transportation technology requires the establishment of a maglev transportation technical standard system. It should follow the principles:

1) Comply with national laws, regulations and mandatory standards.

2) Based on current international standards, national standards and industry standards.

3) Focus on the unique technology of maglev transportation.

According to the basic classification of Chinese standards, standards can be divided into two categories: product categories and engineering construction. The basic structure and format of product standards follow the requirements of GB/T 1.1-2009 Directives for standardization - Part 1: Structure and drafting of standards [5]. The basic structure and format of engineering construction standards follow the Engineering Standards Preparing Regulations (Jian Biao, 2008, No. 182) [6].

According to the technical application scope of standard technical content, standards can be divided into basic standards, general standards and specific standards.

The basic standards for maglev transportation technology are mainly related national basic standards, basic industry standards, and basic standards specific to maglev, such as terminology standards. The general standard is the general technical requirements for the systems, subsystems of maglev transportation technology; the specific standards are the technical requirements for the design, manufacture, installation, acceptance, operation and maintenance of various subsystems, specialized or key equipment and components.

The development of maglev transportation technical standards should focus on the maglev vehicles, tracks, turnouts, propulsion and power supply system, operation control, and maintenance technologies. Therefore, it is needed to construct the maglev transportation technical framework (shown in Fig. 1).

The establishment of a maglev transportation technical standard system can provide guidance for the application, establishment, research and drafting of maglev transportation technical standards.

\section{PROGRESS MADE AND PROSPECT OF MAGLEV TECHNOLOGY STANDARDIZATION}

In order to promote the engineering of maglev transit, China has given full play to the enthusiasm of maglev transportation technology standardization at multi-level standardization bodies and related research, design, manufacture, construction, installation, operation and maintenance units, and has developed some maglev transportation technology standards. 


\subsection{Build multiple levels of maglev technology standardization working mechanism}

According to different levels and types of China's standards, the development of basic standards and general standards for maglev transportation technology is usually supported by national, industry and provincial standardization bodies, the development of specific standards of maglev transportation technology is usually supported by social standardization bodies and companies. Therefore, according to the level and type of standard to be developed, the chief development organization should submit standard project application to standardization bodies, and form the standard working group according to the professional characteristics of each relevant unit and the willingness to participate in the standard preparation.

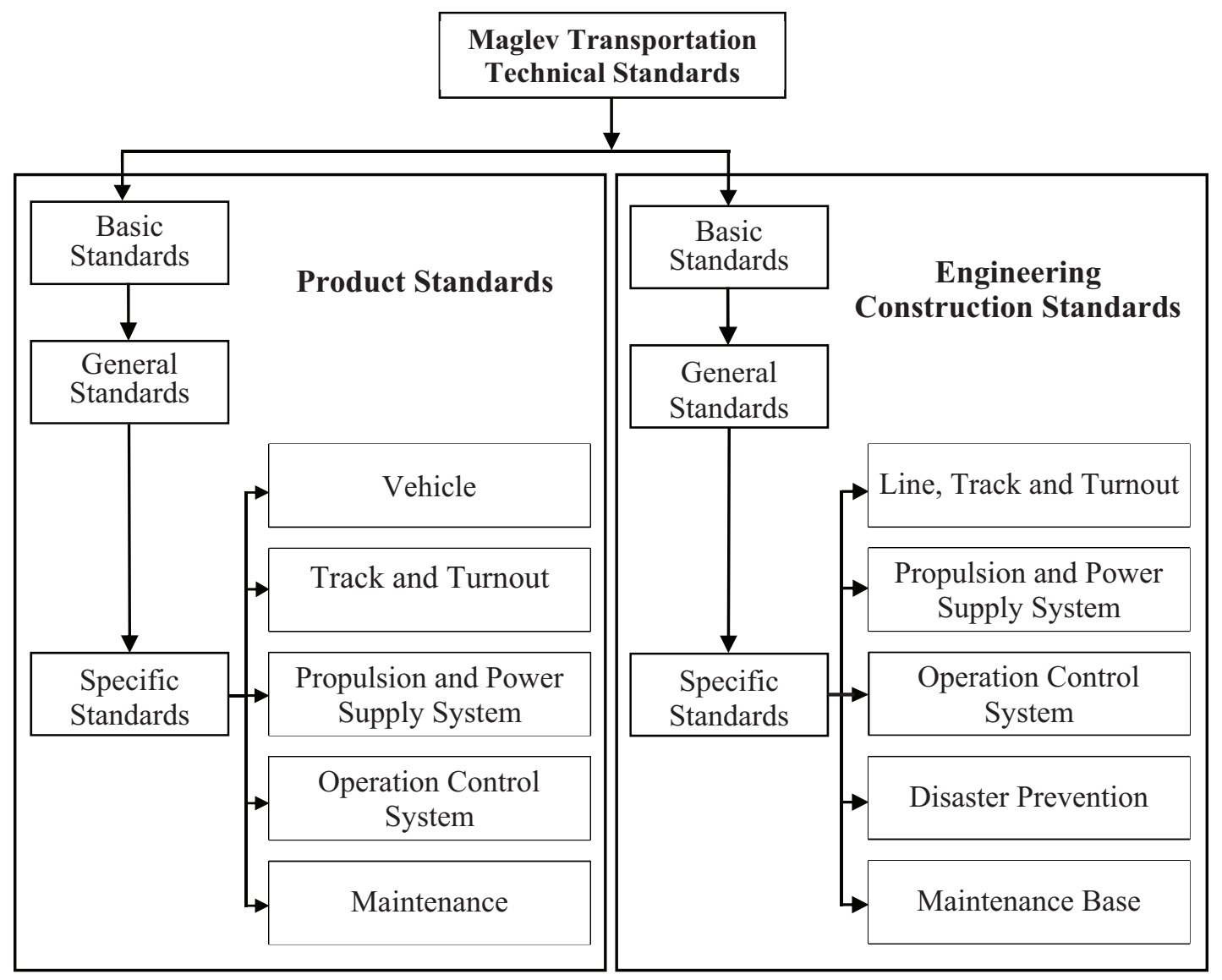

Fig. 1. Maglev Technical Standard System Framework

\subsection{Progress in maglev technology standardization}

Since 2006, China's maglev transportation technology related research, design, manufacture, construction and operation units have actively carried out 
research and drafting of maglev transportation technology standards. At present, 2 high-speed maglev transportation industry standards have been issued (see Table 1), 10 medium and low speed maglev transportation industry and provincial standards have been issued (see Table 2).

Table 1. Issued standards of high-speed maglev transportation

\begin{tabular}{|l|l|c|}
\hline No & \multicolumn{1}{|c|}{ Standard title } & Standard code \\
\hline 1 & $\begin{array}{l}\text { High-speed maglev transportation construction standard (for trial } \\
\text { implementation) }\end{array}$ & JianBiao 161 - 2012 \\
\hline 2 & General specification for high-speed maglev vehicle & CJ/T 367 - 2011 \\
\hline
\end{tabular}

Table 2. Issued standards of medium and low speed maglev transportation

\begin{tabular}{|l|l|l|}
\hline No & \multicolumn{1}{|c|}{ Standard title } & \multicolumn{1}{|c|}{ Standard code } \\
\hline 1 & $\begin{array}{l}\text { General technical specification for medium and low speed } \\
\text { maglev vehicle }\end{array}$ & CJ/T $375-2011$ \\
\hline 2 & $\begin{array}{l}\text { Technical specification for electrical system of medium and } \\
\text { low speed maglev vehicle }\end{array}$ & CJ/T $411-2012$ \\
\hline 3 & $\begin{array}{l}\text { Technical specification for medium and low speed maglev } \\
\text { turnout }\end{array}$ & CJ/T 412-2012 \\
\hline 4 & $\begin{array}{l}\text { Technical specification for medium and low speed maglev } \\
\text { transport rail row }\end{array}$ & CJ/T 413-2012 \\
\hline 5 & $\begin{array}{l}\text { Technical specification of system for the levitation control of } \\
\text { medium and low speed maglev transportation vehicle }\end{array}$ & CJ/T 458-2014 \\
\hline 6 & $\begin{array}{l}\text { Technical code for automatic train control of medium and low } \\
\text { speed maglev transit }\end{array}$ & CJJ/T 255-2017 \\
\hline 7 & $\begin{array}{l}\text { Power supply technical code for medium and low speed } \\
\text { maglev transportation }\end{array}$ & CJJ/T 256-2017 \\
\hline 8 & Code for design of medium and low speed maglev transit & CJJ/T 262-2017 \\
\hline 9 & $\begin{array}{l}\text { Standard of Hunan for design of medium and low speed } \\
\text { maglev transit }\end{array}$ & DBJ43/T 007-2017 \\
\hline 10 & $\begin{array}{l}\text { Standard of Hunan for quality acceptance of medium and low } \\
\text { speed maglev transit engineering }\end{array}$ & DBJ43/T 201-2017 \\
\hline
\end{tabular}

The publication and implementation of these standards and related enterprise standards laid the foundation for the advancement of maglev transit engineering.

\subsection{Maglev Transportation Technology Standardization Prospect}

With the support of standardization bodies at all levels and the efforts of all related units, maglev transportation technology standardization will be further 
strengthened. There are 12 maglev transportation technical standards under development (see Table 3).

Table 3. Standards of maglev transportation under development

\begin{tabular}{|c|c|}
\hline No & Standard title \\
\hline 1 & Standard of high-speed maglev transit \\
\hline 2 & Code for quality acceptance of medium and Low speed maglev track engineering \\
\hline 3 & $\begin{array}{l}\text { Code for quality acceptance of medium and Low speed maglev turnout system } \\
\text { engineering }\end{array}$ \\
\hline 4 & Code fo rtest of medium and Low speed maglev train \\
\hline 5 & General technical specification for medium and low speed maglev vehicle bogie \\
\hline 6 & Technical specification of electromagnet for medium and low speed maglev vehicle \\
\hline 7 & $\begin{array}{l}\text { Rules for inspecting and testing of medium and low maglev vehicle after completion } \\
\text { of construction }\end{array}$ \\
\hline 8 & Technical code for detection of medium and low speed maglev turnout \\
\hline 9 & $\begin{array}{l}\text { Code for quality acceptance of medium and low speed maglev automatic train control } \\
\text { system engineering }\end{array}$ \\
\hline 10 & $\begin{array}{l}\text { Technical specification of suspension system for medium and low speed maglev } \\
\text { vehicle }\end{array}$ \\
\hline 11 & $\begin{array}{l}\text { Technical specification of contact rail for medium and low speed maglev transit } \\
\text { power supply }\end{array}$ \\
\hline 12 & Technical specification of brake system for medium and low speed maglev train \\
\hline
\end{tabular}

In order to regulate and guide the activities related to the research, design, manufacture, construction, and operation of maglev transportation technology, various maglev transportation technology related units have also developed company standards related to maglev transportation technology.

It can be predicted that in the next few years, with the advancement of China's maglev transportation technology research and engineering, China's maglev standardization work will develop faster.

\section{EXPERIENCE}

1) The promotion of maglev transportation engineering has become an increasingly urgent requirement for maglev transportation technology standards.

2) Maglev standardization should be based on relevant research, experiments and engineering practices.

3) The standardization of maglev transportation technology should give full play to the respective advantages of each research, manufacturing, design, 
construction and operation unit, Multiple units may joint for maglev transportation standard development.

4) Strengthen the international exchange of maglev transportation technology standardization.

\section{ACKNOWLEDGEMENT}

This paper is supported by Hunan provincial science and technology major project, "medium and low speed maglev train integrated technology engineering and high reliability operation demonstration" (Porject No.: 2015GK1001).

\section{References}

1. National Bureau of Statistics. Statistical Bulletin of the People's Republic of China on National Economic and Social Development in 2017. [cited 2018 Jul 9]. Available from: http://www.stats.gov.cn/tjsj/zxfb/201802/t20180228_1585631.html (In China).

2. Ministry of Transport. Statistics and Development Bulletin of the Transport Industry in 2017. [cited 2018 Jul 9]. Available from: http://zizhan.mot.gov.cn/zfxxgk/bnssj/zhghs/201803/ t20180329_3005087.html (In China).

3. China Railway Corporation. The completion of major national railway indicators in 2017. [cited 2018 Jul 9]. Available from: http://www.china-railway.com.cn/cpyfw/tjxx/201803/ t20180328_70385.html (In China).

4. China Association of Metros. Statistical Report 2017. Available from: http://www.camet. org.cn/index.php? $m=$ content\& $c=$ index $\& a=$ show $\&$ catid $=18 \& i d=13532$. (In China).

5. China Standard Press. Directives for standardization - Part 1:Structure and drafting of standards. Beijing, China. 2009 (In China).

6. Ministry of Housing and Urban-Rural Development Standards Quota Division. Guidelines for the preparation of engineering construction standards. Beijing: China Architecture \& Building Press. 2009 (In China).

\section{Information about the author:}

Yan Peiliang, Marster Degree, Senior Engineer;

ORCID: 0000-0002-0995-5394;

E-mail: Yanpeiliang@tongji.edu.cn

\section{To cite this article:}

Yan P. Progress made and Prospect of China's Maglev Transportation Technology Standardization. Transportation Systems and Technology. 2018;4(3suppl. 1):246-252. doi: 10.17816/transsyst 201843s1246-252 